\title{
DAMPAK REALISASI TAX AMNESTY TERHADAP INDUSTRI PASAR MODAL MELALUI DANA REPATRIASI
}

\author{
In'am Widiarma \\ Sekolah Tinggi Ilmu Ekonomi Indonesia (STIESIA) Surabaya \\ e-mail: in'amwidiarma@stiesia.ac.id
}

\begin{abstract}
This study is to comprehend the impact of Tax Amnesty policy through capital inflows into equity market effectively. Herewith, there are several of investment instruments in equity market that would be possible to receive all the capital or asset from the taxpayers who puts their money abroad and they will be repatriation to Indonesia. In 2018, open information regarding Taxation and Banking (Automatic Exchange of Information) internationally, in order to no one of country could hide the asset of the taxpayer in other country or otherwise. The excess of capital inflows in equity market would be increase the liquidity of Indeks or financial institutions in equity market sector as whole. Hence, there are elements of company's listed in stock market such as state owned company, private company and government company, they having finance in result for capital expenditures, job creation and boosting the economy of the country. Therefore the repatriation is a way to serve or contribute our country by Indonesian citizen for developing our country with dignity
\end{abstract}

Keywords: tax amnesty, repatriation, taxpayer

\section{PENDAHULUAN}

\section{Latar Belakang}

Amnesti pajak adalah kebijakan pemerintah yang berkaitan dengan pengampunan pajak terhadap warga negara yang selama ini belum melaporkan pajaknya ataupun menyembunyikan kekayaannya sehingga tidak membayar pajak. Kebijakan tax amnesty oleh Pemerintah Jokowi saat ini bukanlah yang pertama kalinya di Indonesia. Amnesti Pajak pernah dilaksanakan pada tahun 1964 dan 1984, dan keduanya gagal dikarenakan keadaan politik dan ekonomi yang saat itu sedang tidak stabil, misalnya, lebih mengembalikan dana revolusi, payung hukumnya hanya keputusan Presiden, terjadi gerakan 30 September: perseteruan antara pemegang kekuasaan, Partai Komunis Indonesia dan tentara. Di tahun 2008, Pemerintah Susilo Bambang Yudhoyono juga melakukan kebijakan sunset policy, yaitu fasilitas penghapusan sanksi administrasi perpajakan.
(Brotodihardjo R. Santoso) menyebutkan bahwa: "Pajak adalah iuran kepada negara (yang dapat dipaksakan) yang terutang oleh yang wajib membayarnya menurut peraturan-peraturan, dengan tidak mendapat prestasi kembali yang langsung ditunjuk, dan yang gunanya adalah untuk membiayai pengeluaran-pengeluaran umum berhubungan dengan tugas negara yang menyelenggarakan pemerintahan”.

Pada khususnya, Tax Amnesty atau pengampunan pajak merupakan penghapusan atau pengurangan pajak terhadap properti yang dimiliki oleh perusahaan, secara umum tax amnesty merupakan penghapusan pajak bagi wajib pajak yang selama ini menimbun dananya di luar negeri dan menghindar dari kewajiban pembayaran pajak dengan imbalan pembayaran tarif lebih rendah.

Di atur dalam UU amnesti pajak nomor 11 tahun 2016, hal-hal yang berkaitan dalam UU tersebut adalah penghapusan pajak terutang, penghapusan sanksi pidana pada bidang perpajak- 
an, maupun sanksi pidana tertentu yang diharuskan. Tujuan tax amnesty antara lain:

1. meningkatkan penerimaan pajak dalam jangka pendek

2. menambah jumlah wajib pajak

3. mengintegrasikan sektor informal ke dalam sistem perekonomian

4. memanfaatkan dana yang tidak terpakai

5. langkah awal kebijakan rezim baru untuk menerapkan sanksi yang lebih besar

Pada tahun 2018 keterbukaan informasi perpajakan dan perbankan (Automatic Exchange of Information) secara internasional sehingga tidak ada satu negara pun di dunia yang bisa menyembunyikan harta kekayaan wajib pajak yang ada di luar negeri atau sebaliknya. Maka dengan adanya kebijakan tax amnesty ini merupakan kesempatan yang tepat bagi para wajib pajak untuk melaporkan kekayaan atau harta yang belum terdaftar atau yang belum membayar pajak.

Dana yang masuk ke industri Pasar Modal dapat meningkatkan likuiditas di bursa maupun di lembaga-lembaga keuangan di pasar modal. Akibat dari hal tersebut perusahaan-perusahaan atau emiten yang ada di pasar modal seperti BUMN, swasta maupun pemerintah dapat melakukan financing atau pendanaan yang hasilnya diperuntukkan untuk modal usaha dan pembangunan perekonomian negara. Oleh karena itu, dengan adanya repatriasi merupakan kontribusi nyata rakyat Indonesia untuk membangun bangsa Indonesia yang bermartabat.

\section{Pertanyaan Penelitian}

Dengan latar belakang tersebut, maka terdapat beberapa point issues yaitu, (a) latar belakang pelaksanaan kebijakan tax amnesty dan (b) kondisi industri pasar modal di Indonesia.
Lebih detail, penelitian akan difokuskan pada permasalahan: Bagaimana dampak realisasi kebijakan tax amnesty terhadap industri pasar modal melalui dana repatriasi di Indonesia?

\section{Tujuan Penelitian}

Tujuan penelitian ini adalah untuk mengetahui seberapa besar dampak kebijakan tax amnesty secara efektif melalui aliran dana yang masuk ke industri pasar modal. Dengan adanya beragam instrumen investasi di pasar modal sangat memungkinkan sebagai penampungan dana atau harta kekayaan wajib pajak yang ada di luar negeri untuk melakukan repatriasi yaitu pembalikan dana ke Indonesia.

Berdasarkan latar belakang dan pernyataan penelitian di atas maka tujuan yang ingin dicapai dalam penelitian ini adalah sebagai berikut.

1. Menganalisis implementasi dan dampak kebijakan tax amnesty terhadap industri pasar modal melalui dana repatriasi di Indonesia.

2. Menemukan rekomendasi bagi kebijakan pemerintah yang berkaitan dengan industri pasar modal ke depannya.

\section{Manfaat Penelitian}

Penelitian ini nantinya akan menelaah secara lebih detail dan komprehensif mengenai dampak kebijakan amnesti pajak saat ini terhadap pasar modal Indonesia. Juga meneliti lebih dalam mengenai seberapa efektifkah kebijakan tax amnesty untuk menggerakkan perekonomian Indonesia melalui dana repatriasi di pasar modal Indonesia.

\section{Ruang Lingkup Penelitian}

Dari penjabaran di atas bahwa industri pasar modal itu identik dengan IHSG (Indeks 
Harga Saham Gabungan), jadi IHSG ini menjadi indikator utama dari semua instrumen investasi yang ada di pasar modal, maka ruang lingkup penelitian ini hanya pada variabel pergerakan tingkat IHSG dan dana repatriasi.

\section{TINJAUAN PUSTAKA}

Menurut (Ujianto Srie Amin 2017:62) Pengampunan pajak atau tax amnesty adalah kebijakan pemerintah di bidang perpajakan yang memberikan penghapusan pajak yang seharusnya terutang dengan membayar tebusan dalam jumlah tertentu yang bertujuan untuk memberikan tambahan penerimaan pajak dan kesempatan bagi wajib pajak yang tidak patuh menjadi wajib pajak yang patuh. Pengampunan pajak mengacu pada dua UU atau undang-undang yaitu UU APBNP 2016 dan UU Republik Indonesia No. 11 tahun 2016 tentang pengampunan pajak atau pengurangan pajak terhadap property yang dimiliki oleh perusahaan dalam bentuk penghapusan pajak terutang, penghapusan sanksi pajak terutang, penghapusan sanksi pidana tertentu yang diharuskan membayar dengan uang tebusan. Kebijakan program Amnesti Pajak pelaksanaannya berjalan selama sembilan bulan mulai tanggal 1 Juli 2016 sampai akhir Maret 2017 dengan di bagi menjadi 3 periode, pemerintah menerapkan tarif tebusan melalui tiga tahap, sebagai berikut.

Tabel 1

Tarif Tebusan Berdasarkan Periode Tax Amnesty

\begin{tabular}{lccc}
\hline \hline \multicolumn{4}{c}{ Tarif Tebusan } \\
\hline & $\begin{array}{c}\text { Periode I } \\
\text { 1 Juli-30 Sept } \\
\mathbf{2 0 1 6}\end{array}$ & $\begin{array}{c}\text { Periode II } \\
\text { 1 Okt-31 Des } \\
\mathbf{2 0 1 6}\end{array}$ & $\begin{array}{c}\text { Periode III } \\
\text { 1 Jan-31 Maret } \\
\mathbf{2 0 1 7}\end{array}$ \\
\hline $\begin{array}{l}\text { Repatriasi/deklarasi } \\
\text { dalam negeri }\end{array}$ & $2 \%$ & $3 \%$ & $5 \%$ \\
\hline Deklarasi luar negeri & $4 \%$ & $6 \%$ & $10 \%$ \\
\hline $\begin{array}{l}\text { UMKM dengan deklarasi } \\
\text { nilai harta < 10 miliar }\end{array}$ & & $0,5 \%$ & \\
\hline $\begin{array}{l}\text { UMKM dengan deklarasi } \\
\text { nilai harta > 10 miliar }\end{array}$ & & $2 \%$ & \\
\hline
\end{tabular}

Sumber: Direktorat Jenderal Pajak
Berdasarkan tarif pajak penghasilan pribadi menurut UU Republik Indonesia Pasal 17 Ayat 1 Undang-Undang No. 36 Tahun 2008 tentang pajak penghasilan, maka tarif potongan pajak penghasilan pribadi sebagai berikut.

Tabel 2

Besarnya Tarif Pajak Berdasarkan Penghasilan Kena Pajak

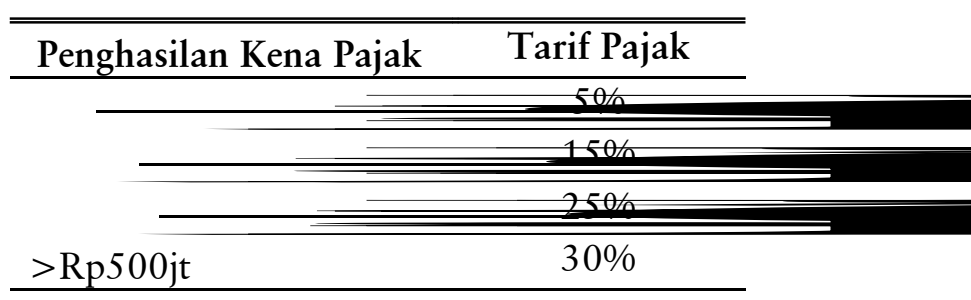

Sumber: Direktorat Jenderal Pajak

Sesuai amanat Undang-Undang Pengampunan Pajak, dana repatriasi harus diinvestasikan di dalam negeri selama minimum tiga tahun dalam instrumen investasi. Kedelapan instrumen investasi yang dimaksud yaitu terdiri dari: SBN, Obligasi Badan Usaha Milik Negara (BUMN), obligasi lembaga pembiayaan yang dimiliki oleh pemerintah, investasi keuangan pada Bank Persepsi.

Pengertian Investasi yang lebih luas membutuhkan aktiva yang produktif untuk mengubah satu unit konsumsi yang ditunda untuk dihasilkan menjadi lebih dari satu unit konsumsi mendatang. Dengan demikian, investasi dapat didefinisikan sebagai penundaan konsumsi sekarang untuk dimasukkan ke aktiva produktif selama periode waktu yang tertentu.

Investasi ke dalam aktiva keuangan dapat berupa investasi langsung dan tidak langsung. Investasi langsung dilakukan dengan membeli langsung aktiva keuangan dari suatu perusahaan baik melalui perantara atau dengan cara yang lain. Sebaliknya investasi tidak langsung dilakukan dengan membeli saham dari perusahaan investasi yang mempunyai portofolio aktivaaktiva keuangan dari perusahaan-perusahaan 
lain. Investasi langsung dapat dilakukan dengan membeli aktiva keuangan yang dapat diperjualbelikan di pasar uang (money market), pasar modal (capital market), atau pasar turunan (derivative market). Investasi langsung juga dapat dilakukan dengan membeli aktiva keuangan yang tidak dapat diperjualbelikan. Aktiva keuangan yang tidak dapat diperjualbelikan biasanya diperoleh melalui bank komersial, aktiva-aktiva ini dapat berupa tabungan di bank atau sertifikat deposito.

Investasi tidak langsung dilakukan dengan membeli surat-surat berharga dari perusahaan investasi. Perusahaan Investasi adalah perusahaan yang menyediakan jasa keuangan dengan cara menjual sahamnya ke publik dan menggunakan dana yang diperoleh untuk diinvestasikan ke dalam portofolionya. Ini berarti perusahaan investasi membentuk portofolio (diharapkan portofolionya optimal) dan menjualnya eceran kepada publik dalam bentuk saham-sahamnya.

Pasar modal adalah kegiatan yang berhubungan dengan penawaran umum atau IPO (Initial Public Offerings) dan perdagangan efek, perusahaan publik yang berkaitan dengan efek yang diterbitkannya, serta lembaga dan profesi yang berkaitan dengan efek. Pasar Modal merupakan investasi alternatif selain dari investasi konservatif yang biasa disebut investasi perbankan seperti tabungan, deposito dan lain-lain, banyak produk-produk yang ada di pasar modal misalkan obligasi, reksadana, dan saham.

Pasar modal merupakan sarana perusahaan untuk meningkatkan kebutuhan dana jangka panjang dengan menjual saham atau mengeluarkan obligasi. Untuk menarik pembeli dan penjual agar berpartisipasi, pasar modal harus bersifat liquid dan efisien. Suatu pasar modal dikatakan liquid jika penjual dapat menjual dan pembeli dapat membeli surat-surat berharga dengan cepat. Pasar modal dikatakan efisien jika harga dari surat-surat berharga mencerminkan nilai dari perusahaan secara akurat.

Jika pasar modal sifatnya efisien, harga dari surat berharga juga mencerminkan penilaian dari investor terhadap prospek laba perusahaan di masa mendatang, serta kualitas dari manajemennya. Jika calon investor meragukan kualitas dari manajemen, keraguan ini dapat terlihat dari harga surat berharga yang turun. Dengan demikian pasar modal dapat digunakan sebagai sarana tidak langsung pengukur kualitas manajemen. Juga pemegang saham mempunyai hak mengawasi manajemen lewat hak veto di dalam pertemuan dan pemilihan manajemen. Hak veto pemegang saham dapat dilakukan langsung atau dapat dialihkan ke pihak kedua lewat suatu wakil atau proksi (proxy). Jika pemegang saham tidak puas dengan manajemen maka dapat terjadi perang proksi (proxy fight) untuk mengganti manajemen.

Pasar modal juga mempunyai fungsi sarana alokasi dana yang produktif untuk memindahkan dana dari pemberi peminjaman ke peminjam. Alokasi dana yang produktif terjadi jika individu yang mempunyai kelebihan dana dapat meminjamkannya ke individu lain yang lebih produktif yang membutuhkan dana. Sebagai akibatnya, peminjam dan pemberi pinjaman akan lebih diuntungkan dibandingkan jika pasar modal tidak ada.

Indeks harga saham gabungan (IHSG) di BEI meliputi pergerakan-pergerakan harga untuk saham biasa dan saham preferen. IHSG mulai dikenalkan pertama kali pada tanggal 1 April 1983 dengan menggunakan landasan dasar (baseline) tanggal 10 Agustus 1982. Jumlah saham tercatat pada waktu itu adalah hanya 13 saham, dasar dari IHSG selalu disesuaikan untuk kejadian seperti IPO, right issue, partial/company listing, konversi dari warrant dan convertible bond dan delisting. Untuk kejadian-kejadian se- 
perti pemecahan lembar saham (stock splits), dividen berupa saham (stock dividends), bonus issue, nilai dari IHSG tidak berubah, karena peristiwa-peristiwa ini tidak mengubah nilai pasar total (Hartono, Jogiyanto, 2010: 102).

Obligasi adalah suatu istilah yang dipergunakan dalam dunia keuangan yang merupakan suatu pernyataan utang dari penerbit obligasi kepada pemegang obligasi beserta janji untuk membayar kembali pokok utang beserta kupon bunganya kelak pada saat tanggal jatuh tempo pembayaran.

Reksadana ialah wadah dan pola pengelolaan dana atau modal bagi sekumpulan investor untuk berinvestasi dalam instrumen-instrumen investasi yang tersedia di pasar dengan cara membeli unit penyertaan reksadana. Dana ini lalu dikelola oleh Manajer Investasi (MI) ke dalam portfolio investasi, baik berupa saham, obligasi, pasar uang ataupun efek atau sekuriti lainnya.

Saham adalah surat berharga yang bisa diperjualbelikan (transaksi) oleh perorangan atau lembaga di pasar tempat surat berharga tersebut diperjualbelikan.

Ada dua keuntungan yang diperoleh investor dengan membeli atau memiliki saham.

1. Dividen, yaitu merupakan pembagian keuntungan yang diberikan perusahaan dan berasal dari keuntungan yang dihasilkan perusahaan, dividen diberikan setelah mendapat persetujuan dari pemegang saham dalam RUPS (rapat umum pemegang saham), jika seorang pemodal ingin mendapatkan dividen maka pemodal tersebut harus memegang saham tersebut dalam kurun waktu yang relatif lama yaitu hingga kepemilikan saham tersebut berada dalam periode di mana diakui sebagai pemegang saham yang berhak mendapatkan dividen.

2. Capital gain, yaitu merupakan selisih antara harga beli dan harga jual, harga beli lebih rendah dari harga jual, capital gain terbentuk dengan adanya aktivitas perdagangan saham di pasar sekunder.

Saham memiliki beberapa risiko sebagai berikut.

1. Capital Loss: Merupakan selisih antara harga beli dan harga jual, namun kebalikan dari capital gain yakni harga beli lebih tinggi dari harga jual.

2. Risiko Likuiditas: Perusahaan yang sahamnya dimiliki, dinyatakan bangkrut oleh pengadilan atau perusahaan tersebut dibubarkan, dalam hal ini hak klaim dari pemegang saham mendapatkan prioritas terakhir setelah seluruh kewajiban perusahaan dapat dilunasi (dari hasil penjualan kekayaan perusahaan), jika masih terdapat sisa dari hasil penjualan kekayaan perusahaan tersebut, maka sisa tersebut dibagi secara proporsional kepada seluruh pemegang saham.

Repatriasi (repatriation) secara harfiah yaitu pengembalian modal yang disimpan di kantor bank luar negeri atau cabang bank di luar negeri ke bank negara asal, sedangkan merujuk pada istilah perpajakan Indonesia dalam konteks repatriasi adalah proses pengembalian akumulasi penghasilan berupa harta atau aset dari luar wilayah NKRI (Negara Kesatuan Republik Indonesia).

\section{HIPOTESIS}

Dari berbagai variabel yang akan diteliti, hipotesis menduga bahwa terdapat dampak yang signifikan antara industri pasar modal dan dana repatriasi yang dilakukan. Terdapat hubungan positif signifikan antara industri pasar modal dengan dana repatriasi. 


\section{METODOLOGI PENELITIAN}

\section{Jenis Penelitian}

Penelitian ini menggunakan metode penelitian kuantitatif. Metode kuantitatif dipergunakan untuk menghitung secara regresi dampak atau signifikansi dana repatriasi yang terkumpul terhadap industri pasar modal di Indonesia. Teknik pengolahan data dengan menggunakan metode korelasi non parametrik disebabkan analisis bertujuan menguji hubungan serta data berskala rasio namun besar sampel yang di bawah 30 maka uji statistik yang relevan adalah korelasi non parametrik.

Setelah dilakukan analisis statistik juga dilakukan analisis yang lebih menekankan pada aspek pemahaman secara mendalam terhadap suatu masalah (in-depth analysis) dengan melakukan analisis dan observasi setelah implementasi kebijakan ini.

\section{Jenis dan Sumber Data}

Jenis data pada penelitian ini adalah data rasio. Sumber data pada penelitian ini terdiri dari dua hal sebagai berikut.

1) Sumber data primer, yaitu sumber data yang diperoleh langsung dari perusahaan efek yang terkait.

2) Sumber data sekunder yaitu sumber data yang diperoleh dari hasil dokumentasi atau sumber informasi lain yang diakui di antaranya data dari Ditjen Pajak dan sumber yang tepercaya lainnya.

\section{Teknik Pengumpulan Data}

Metode pengumpulan data antara lain meliputi: Metode pengumpulan data pada penelitian ini adalah dengan metode dokumentasi dari laporan Ditjen Pajak dan Bursa Efek Indonesia.

\section{Definisi Operasional Variabel dan Pengukuran}

Dana repatriasi adalah pengembalian akumulasi penghasilan berupa harta atau aset dari luar wilayah NKRI (Negara Kesatuan Republik Indonesia) ke dalam wilayah Indonesia yang diperoleh dari adanya program Tax Amnesty.

Aktivitas pasar modal pada penelitian ini diukur dari indeks harga saham gabungan dan return IHSG. Indeks harga saham gabungan adalah indeks yang mencerminkan adanya perdagangan saham atau surat berharga yang bisa diperjualbelikan (transaksi) oleh perorangan atau lembaga di pasar tempat surat berharga tersebut diperjualbelikan.

\section{Teknik Analisis Data}

Teknik analisis data yang digunakan dalam penelitian ini adalah analisis korelasi Pearson. Alasan dipilihnya teknik analisis ini adalah karena bertujuan menguji hubungan antara dana repatriasi dengan aktivitas industri pasar modal di Indonesia. Jenis data yang digunakan adalah rasio. Sebelum dilakukan uji korelasi Pearson dilakukan uji normalitas dengan Saphiro Wilk. Jika hasil pengujian menunjukkan data berdistribusi normal maka uji Pearson bisa dilanjutkan, namun jika tidak normal dilakukan pengujian dengan korelasi Spearman.

Selain itu, pada penelitian ini juga dilakukan pengujian dengan menggunakan uji beda ANOVA untuk melihat rata-rata IHSG dan return IHSG berbeda signifikan pada tiap periode atau tidak berbeda signifikan. Nilai signifikansi yang digunakan adalah 0,05 .

\section{HASIL PENELITIAN DAN PEMBAHASAN}

Program tax amnesty merupakan program yang dilakukan pemerintah Indonesia pada masa 
In'am Widiarma, Dampak Realisasi Tax Amnesty Terhadap Industri Pasar Modal melalui Dana Repatriasi

Tabel 3

Perbandingan Amnesti Pajak Indonesia dan Negara-Negara Lain

\begin{tabular}{lccclccc}
\hline \hline \multicolumn{7}{c}{ Pencapaian Amnesti Pajak } \\
\hline \multicolumn{7}{c}{ Deklarasi Harta } & \multicolumn{5}{c}{ Tebusan } \\
\hline Indonesia & Capaian & GDP & Tahun & Negara & Capaian & GDP & Tahun \\
Italia & $1,179 \mathrm{~T}$ & $21.1 \%$ & Sep 2016 & Indonesia & $97.2 \mathrm{~T}$ & $0.65 \%$ & Sep 2016 \\
Chili & $5.2 \%$ & 2009 & Italia & $59 \mathrm{~T}$ & $0.2 \%$ & 2009 \\
Spanyol & $263 \mathrm{~T}$ & $8.3 \%$ & 2015 & India & $20 \mathrm{~T}$ & $0.58 \%$ & 1997 \\
Afrika Sel. & $115 \mathrm{~T}$ & $3.6 \%$ & 2003 & Spanyol & $18 \mathrm{~T}$ & $0.12 \%$ & 2012 \\
Australia & $66 \mathrm{~T}$ & & 2014 & Belgia & $7 \mathrm{~T}$ & $0.15 \%$ & 2006 \\
Irlandia & $26 \mathrm{~T}$ & & 1993 & Afrika Sel. & $2 \mathrm{~T}$ & $0.17 \%$ & 2003 \\
\hline
\end{tabular}

pemerintahan Presiden Joko Widodo. Program ini merupakan program yang juga dilakukan di beberapa negara lain sebagai sumber pendapatan pemerintah. Berikut Tabel yang menunjukkan perbandingan pendapatan dari tax amnesty dibandingkan dengan Gross Domestic Product (GDP)

Walaupun hasil akhir pengampunan pajak belum mencapai target yang ditetapkan oleh pemerintah, tetapi Indonesia termasuk berhasil dibandingkan dengan negara-negara lain yang telah melakukan Amnesti Pajak, terlihat di Tabel 3 perbandingan hasil deklarasi dan tebusan periode I pengampunan pajak Indonesia saja telah mencapai di atas rata-rata negara-negara lain. Demikian juga bahwa Indonesia masih tertinggi dalam hasil tebusan dan deklarasi terhadap GDP/PDB negara dibandingkan negara-negara lain yakni $0.65 \%$ dan $21,1 \%$.

Apabila melihat hasil dana repatriasi Indonesia terbilang kecil apabila dibandingkan dengan negara lain seperti Italia, dikarenakan wajib pajak orang Indonesia kebanyakan berinvestasi properti di negara lain, sehingga tidak mudah untuk mencairkannya kembali kemudian dipindahkan ke negara asal, sebaliknya di negara Italia banyak mafia yang melakukan kejahatan money laundry kemudian dengan mudah untuk membawa kembali dananya yang berbentuk uang.
Sebelum dilakukan analisis terhadap variabel penelitian maka pada bagian awal akan disajikan analisis secara deskriptif pada masingmasing variabel. Yang pertama adalah hasil pengampunan pajak, baik berupa tebusan, deklarasi dan repatriasi.

\section{Deskripsi Dana Repatriasi}

Tabel 4

Hasil Pengampunan Pajak: Tebusan, Deklarasi, dan Repatriasi

\begin{tabular}{|c|c|}
\hline \multicolumn{2}{|c|}{ Hasil Tax Amnesty } \\
\hline \multicolumn{2}{|l|}{ Periode I } \\
\hline \multicolumn{2}{|l|}{ Juli-September 2016: } \\
\hline Tebusan & $\mathrm{Rp} 97.2 \mathrm{~T}$ \\
\hline Deklarasi & $\operatorname{Rp} 3.483 \mathrm{~T}$ \\
\hline Repatriasi & $\mathrm{Rp} 137 \mathrm{~T}$ \\
\hline \multicolumn{2}{|l|}{ Periode II } \\
\hline \multicolumn{2}{|l|}{ Oktober-Desember 2016: } \\
\hline Tebusan & Rp 103 T \\
\hline Deklarasi & $\mathrm{Rp} 4.296 \mathrm{~T}$ \\
\hline Repatriasi & $\mathrm{Rp} 141 \mathrm{~T}$ \\
\hline \multicolumn{2}{|l|}{ Periode III } \\
\hline \multicolumn{2}{|l|}{ Januari-Maret 2017: } \\
\hline Tebusan & $\mathrm{Rp} 113.9 \mathrm{~T}$ \\
\hline Deklarasi & $\mathrm{Rp} 4.667 \mathrm{~T}$ \\
\hline Repatriasi & Rp $147 \mathrm{~T}$ \\
\hline
\end{tabular}

Tabel 4 menunjukkan ada tiga sumber pendapatan pemerintah dari tax amnesty yaitu tebusan, deklarasi, dan repatriasi. Dari ketiga sumber penghasilan tersebut, deklarasi merupa- 
kan pendapatan terbesar, kemudian repatriasi dan terakhir tebusan. Dana repatriasi yang diterima pemerintah melalui program tax amnesty pada priode I (Juli-September 2016) sebesar Rp 137 triliun. Kemudian pada periode kedua diperoleh dana Rp 141 triliun. Jumlah ini lebih besar dibandingkan periode I. Kemudian pada periode ketiga diperoleh nilai Rp 147 triliun. Perolehan pada periode III ini lebih besar dibandingkan periode II. Selanjutnya akan dilakukan analisis berdasarkan pencapaian realisasi dana repatriasi dibandingkan target.

\section{Tabel 5}

Perbandingan Pencapaian Hasil Pengampunan Pajak: Tebusan, Deklarasi, dan Repatriasi dengan Target

\begin{tabular}{lccc}
\hline \hline \multicolumn{1}{c}{ Jenis } & $\begin{array}{c}\text { Target } \\
(\mathbf{a})\end{array}$ & $\begin{array}{c}\text { Realisasi } \\
(\mathbf{b})\end{array}$ & $\begin{array}{c}\text { \% Pencapaian } \\
(\mathbf{a} / \mathbf{b})\end{array}$ \\
\hline Tebusan & Rp 165 T & Rp 135 T & $81,8 \%$ \\
Deklarasi & Rp 4.000 T & $\operatorname{Rp~4.855~T~}$ & $121,4 \%$ \\
Repatriasi & Rp1.000 T & Rp 147 T & $14,7 \%$ \\
\hline
\end{tabular}

Berdasarkan Tabel 5 maka pencapaian dana repatriasi yang terealisasi $14,7 \%$ dibandingkan target. Sedangkan untuk deklarasi capaian realisasi lebih tinggi dibandingkan dengan target (121,4\%). Untuk dana tebusan capaian realisasi dibandingkan target $81,82 \%$. Berdasarkan persentase tersebut maka pencapaian repatriasi paling rendah dibandingkan dengan yang lain.

\section{Deskripsi IHSG}

Setelah dilakukan analisis pada dana repatriasi maka berikut akan dideskripsikan data IHSG.

Tabel 6

Rerata IHSG pada Tiga Periode Tax Amnesty

\begin{tabular}{lcc}
\hline \hline \multicolumn{1}{c}{ Jenis } & IHSG & Pergerakan \\
\hline Periode I (Juli-September 2016) & 5314 & \\
Periode II (Oktober-Desember 2016) & 5287 & $-0,51 \%$ \\
Periode III (Januari-Maret 2017) & 5383 & $1,82 \%$ \\
\hline
\end{tabular}

Berikut ini adalah data rata-rata harga saham perusahaan di Bursa Efek Indonesia selama tax amnesty. Pada periode pertama rata-rata IHSG 5314. Kemudian pada periode kedua menurun menjadi 5287. Sehingga terjadi penurunan $0,51 \%$. Pada periode ketiga terjadi kenaikan menjadi 5383. Atau terjadi kenaikan 1,82\%. Semakin banyaknya dana repatriasi mengalir ke pasar modal, ini salah satunya dipicu oleh adanya pernyataan dari pemerintah yang sangat menganjurkan agar dana repatriasi tidak hanya dialokasikan atau disimpan di bank tetapi diinvestasikan ke pasar keuangan atau sektor riil.

Selanjutnya, jika dilihat dalam pergerakan IHSG pada tiap bulannya maka grafiknya dapat dilihat pada Gambar 1.

Berdasarkan grafik dapat diketahui bahwa pada periode I, rata-rata IHSG mengalami fluktuasi pada bulan pertama sampai ketiga. Kemudian pada periode II, IHSG cenderung mengalami tren penurunan pada bulan pertama sampai

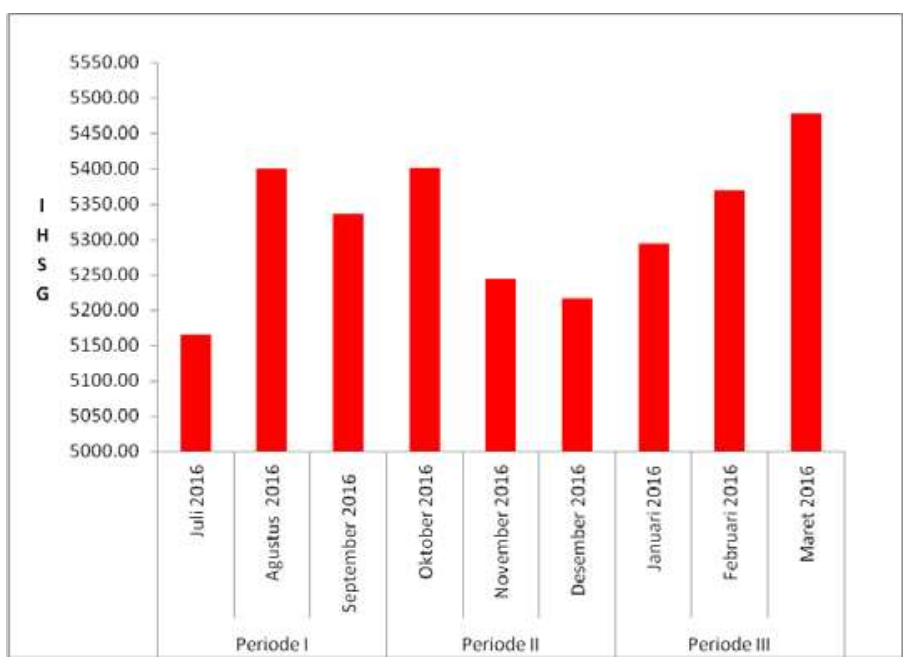

Gambar 1

Rerata IHSG Setiap Bulan pada Periode I hingga Periode III

bulan ketiga. Hasil berbeda ditunjukkan pada IHSG periode III. IHSG menunjukkan adanya kenaikan trend. Bulan kedua meningkat diban- 
dingkan pertama, dan selanjutnya yang paling tinggi adalah bulan ketiga.

Selain dilakukan analisis berdasarkan nilai IHSG pada penelitian ini juga dilakukan perhitungan nilai return IHSG. Berikut return IHSG atau return pasar selama periode tax amnesty.

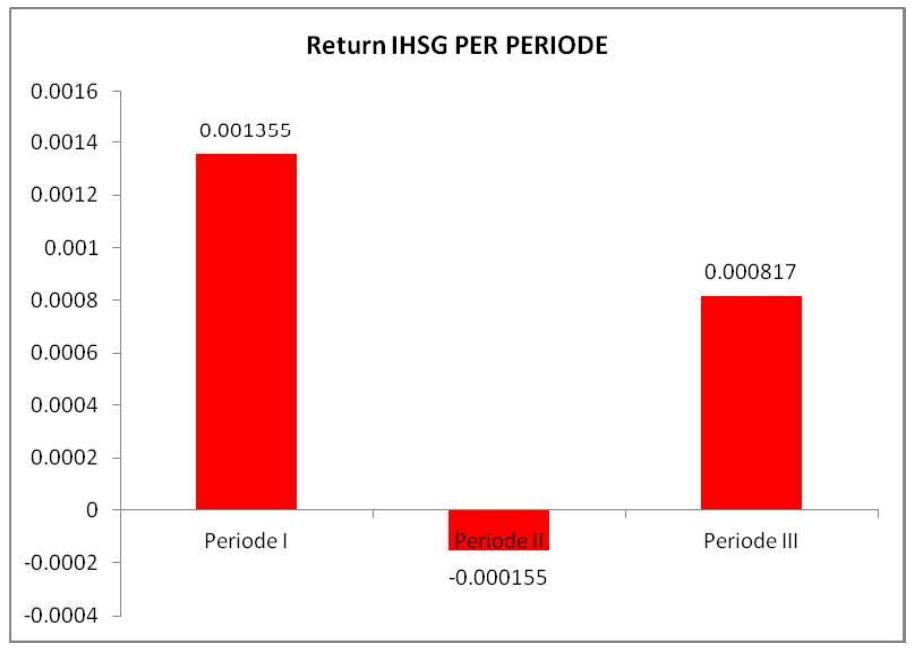

Gambar 2

Rerata Return IHSG pada Periode I hingga Periode III

Berdasarkan Gambar 2 return tertinggi IHSG diperoleh pada periode pertama, kemudian periode III. Sedangkan pada periode kedua diperoleh return negatif.

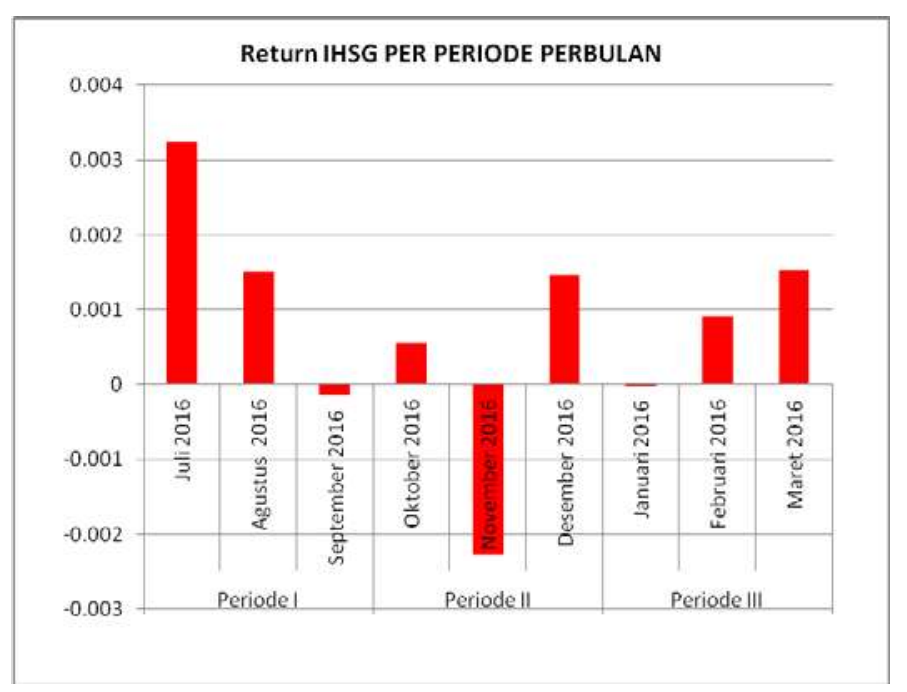

Gambar 3

Rerata Return IHSG Setiap Bulan pada Periode I hingga Periode III
Berdasarkan Gambar 3 maka return tertinggi IHSG diperoleh pada bulan Juli periode pertama. Kemudian menurun pada bulan Agustus dan bernilai negatif pada bulan September. Kemudian pada periode II, return tertinggi selama bulan Desember, kemudian bulan Oktober. Pada bulan November terdapat return ISH negatif. Pada periode III menunjukkan adanya kenaikan dari bulan pertama sampai bulan ketiga. Di antara seluruh bulan dilaksanakannya tax amnesty, return IHSG tertinggi pada bulan Juli 2016.

\section{Hubungan Repatriasi dengan IHSG}

Keterkaitan antara repatriasi dengan IHSG akan dilakukan dengan beberapa uji. Pertama adalah uji korelasi Pearson. Sebelum dilakukan uji korelasi Pearson maka dilakukan uji normalitas data dengan Saphiro Wilk. Jika data berdistribusi normal maka dilakukan pengujian dengan Pearson, namun jika tidak normal dilakukan pengujian dengan Spearman. Berikut adalah hasil uji normalitas.

Tabel 7

Uji Normalitas Data

\begin{tabular}{l|c|c|l}
\hline \hline \multirow{2}{*}{ Variabel } & \multicolumn{3}{|c}{ Saphiro Wilk } \\
\cline { 2 - 4 } & Statistic & Sig. & Keterangan \\
\hline IHSG & 0.943 & 0.618 & Normal \\
\hline Return IHSG & 0.812 & 0.028 & Tidak normal \\
\hline Repatriasi & 0.974 & 0.929 & Normal \\
\hline
\end{tabular}

Hasil perhitungan menunjukkan data IHSG dan return IHSG berdistribusi normal ( $p>0,05)$, sedangkan data repatriasi tidak berdistribusi normal $(p<0,05)$. Oleh karena data repatriasi tidak berdistribusi normal maka uji korelasi yang digunakan adalah Spearman. Berikut hasil perhitungan Spearman untuk hubungan IHSG dan return IHSG dengan dana repatriasi. 
Tabel 8

Uji Korelasi IHSG, Return IHSG dengan Repatriasi

\begin{tabular}{llc}
\hline \hline \multicolumn{2}{c}{ Spearman's rho } & Repatriasi \\
\hline \multirow{2}{*}{ IHSG } & Koefisien & 0,316 \\
\multirow{2}{*}{ Return IHSG } & Sig. & 0,407 \\
& Koefisien & $-0,580$ \\
& Sig. & 0,102 \\
\hline
\end{tabular}

Hasil penelitian menunjukkan arah hubungan IHSG dengan repatriasi adalah positif dengan nilai koefisien 0,316. Arti positif tersebut adalah semakin meningkat dana repatriasi yang diperoleh maka semakin meningkat IHSG di pasar modal. Hasil signifikansi diperoleh nilai 0,407 ( $p>0,05)$. Ini berarti hubungan IHSG dengan dana repatriasi tidak signifikan.

Hasil penelitian juga menunjukkan arah hubungan return IHSG dengan repatriasi adalah negatif dengan nilai koefisien -0,580. Arti negatif menunjukkan semakin meningkat dana repatriasi yang diperoleh maka semakin menurun return IHSG di pasar modal. Hasil signifikansi diperoleh nilai $0,102(p>0,05)$. Ini berarti hubungan return IHSG dengan dana repatriasi tidak signifikan.

Penelitian ini juga melakukan pengujian dengan menggunakan uji beda untuk melihat nilai IHSG dan return IHSG selama periode tax amnesty. Perhitungan uji beda yang dilakukan adalah dengan menggunakan uji ANOVA dan hasil selengkapnya dapat dilihat pada Tabel 9.
Hasil perhitungan uji ANOVA menunjukkan bahwa nilai IHSG tidak berbeda signifikan $(p>0,05)$ pada ketiga periode tax amnesty. Demikian juga nilai return IHSG juga menunjukkan tidak ada perbedaan signifikan $(\mathrm{p}>0,05)$ pada ketiga periode tax amnesty.

\section{SIMPULAN DAN SARAN}

\section{Simpulan}

Berdasarkan hasil penelitian dan pembahasan bahwa pemerintah telah melakukan hal yang baik dalam pembenahan sistem perpajakan di Indonesia, dengan melakukan amnesti pajak ini pemerintah melalui Direktorat Pajak mengajak masyarakat secara sukarela mendaftarkan diri sebagai wajib pajak (apabila belum menjadi wajib pajak), yang sudah menjadi wajib pajak bisa melaksanakan haknya untuk melakukan pengampunan pajak seperti penghapusan pajak terutang, penghapusan sanksi pajak terutang, penghapusan sanksi pidana tertentu yang diharuskan membayar dengan uang tebusan. Pada program tax amnesty ini yang berbeda yaitu dibagi dalam tiga periode dengan memiliki perbedaan tarif tebus tiap periodenya, tarif yang jauh lebih murah. Oleh karena itu, kepercayaan antara pemerintah dan wajib pajak harus mulai tumbuh, perbaikan internal aparatur pajak pun sudah dilakukan oleh pemerintah begitu juga pada wajib pajak yang selama ini tidak jujur terhadap

Tabel 9

Uji Beda IHSG dan Return IHSG Berdasarkan Periode Tax Amnesty

\begin{tabular}{llcccc}
\hline \hline & & N & Mean & Std. Deviation & Sig Uji F \\
\hline IHSG & Periode I & 3 & 5301.0100 & 121.54441 & \\
& Periode II & 3 & 5288.0433 & 99.60085 & 0,542 \\
& Periode III & 3 & 5380.6300 & 92.48552 & \\
\multirow{2}{*}{ Return IHSG } & Periode I & 3 & .0012933 & .00033292 & \\
& Periode II & 3 & .0015767 & .00162574 & 0,152 \\
& Periode III & 3 & -.0006267 & .00147399 & \\
\hline
\end{tabular}


pajak dapat melaksanakan kewajibannya sebagai warga negara yang taat supaya tercapainya sistem perpajakan yang kredibel dan akuntabel.

Secara efektif, pemerintah sudah melakukan kebijakan tax amnesty ini lebih baik dibandingkan dua periode (tahun 1964 \& 1984) kebijakan pengampunan pajak terdahulu, karena program ini didukung oleh beberapa hal yaitu: sumber daya aparatur pajak yang memadai dan bersih (tidak korupsi), kondisi ekonomi negara yang stabil, meningkatkan dana masuk ke Indonesia yang hasilnya dapat diperuntukkan untuk pembangunan infrastruktur, berdampak positif terhadap pasar keuangan dan bursa efek Indonesia.

Dana repatriasi secara keseluruhan yang masuk ke pasar modal kurang dari 10\% dari total repatriasi yaitu Rp $147 \mathrm{~T}$ terbilang kecil. Banyak dana repatriasi yang masuk ke instrumen reksadana dan SBN pemerintah, berarti wajib pajak lebih berminat pada instrumen investasi yang risiko rendah dan keuntungan yang menarik, oleh sebab itu pemerintah maupun lembaga keuangan yang ditunjuk sebagai gateway atau penampungan pajak harus bisa memberikan wadah investasi yang menarik dibandingkan investasi yang ada di luar negeri untuk jangka waktu yang panjang dan berkesinambungan, kendala lain yang masih dialami wajib pajak banyak dana yang mereka investasikan di negara lain lebih kepada investasi properti seperti rumah, tanah, apartmen, dan lain-lain sehingga wajib pajak kesulitan untuk memindahkan dana dengan waktu periode tertentu.

Hasil perhitungan statistik menunjukkan tidak ada hubungan yang signifikan antara IHSG dengan dana repatriasi. Demikian juga hasil perhitungan return IHSG dengan dana repatriasi. Hasil perhitungan korelasi juga menunjukkan hasil yang tidak signifikan.

\section{Saran}

Berdasarkan kesimpulan penelitian ini, maka saran yang dapat diberikan oleh peneliti adalah: Pemerintah dalam hal ini OJK (Otoritas Jasa Keuangan), BEI (Bursa Efek Indonesia), SelfRegulatory Organization (SRO) yakni KSEI/KPEI dan unsur-unsur lain penunjang industri pasar modal harus saling bekerjasama untuk merumuskan atau merancang kebijakan dan instrumen investasi di dalam negeri aman dan menarik dibandingkan investasi di luar negeri.

\section{DAFTAR RUJUKAN}

Broker dan Dealer. 2007. Modul Pelatihan. Jakarta: Bursa Efek Indonesia. . 2013. Modul Pelatihan Wakil Perantara Pedagang Efek. TICMI (The Indonesia Capital Market Institute).

Eduard Fernando dan Ni Putu Santi Suryantini. 2018. Dampak Pengumuman Tax Amnesty pada Saham LQ-45 BEI. E-Jurnal Manajemen Unud, 7 (1):360-386.

Hartono, Jogiyanto. 2012. Teori Portfolio dan Analisis Portfolio, Edisi Ketiga. Yogyakarta: BPFE UGM.

Hassett, A. Kevin and R. Glenn Hubbard. 1996. Tax Policy and Investment. This Paper was Presented at the Conference on Fiscal Policy: Lessons from Economic. Research, Robert D. 1996. Burch Center for Tax Policy and Public Finance, University of California, Berkeley, February 2-3. http://www.nber.org/papers/w5683.pdf.

Husnan, Suad. 1998. Dasar-Dasar Teori Portofolio dan Analisis Sekuritas, Edisi Ketiga. Yogyakarta: Sekolah Tinggi Ilmu Manajemen YKPN.

Husnan, Suad. 2005. Dasar-Dasar Teori Portofolio dan Analisis Sekuritas, Edisi Keempat. 
Yogyakarta: Sekolah Tinggi Ilmu Manajemen YKPN.

Mardiasmo. 2011. Perpajakan Edisi Revisi. Yogyakarta: Andi.

Naihasy, Syahrin. 2006. Kebijakan Publik (Public Policy) Menggapai Masyarakat Madani. Yogyakarta: Midi Pustaka.

Sondang, P. Siagian. 1985. Administrasi Pembangunan. Jakarta: Bumi Aksara.

Sumitro, Rokhmat, Raden. 1993. Pajak Penghasilan, Edisi Revisi. Bandung: Eresco.

Sutra Manik, Jullie J. Sondakh, dan Sintje Rondonuwu. 2017. Analisis Reaksi Harga Saham Sebelum dan Sesudah Tax Amnesty Periode Pertama (Studi Kasus Saham Sektor Properti Yang Tercatat Di Bursa Efek Indonesia). Jurnal EMBA, 5 (2):762-772.

Tandelilin, Eduardus. 2001. Analisis Investasi dan Manajemen Portofolio, Edisi Pertama. Yogyakarta: BPFE.
The World Bank. 2013. World Bank Open Data [Data file]. Retrieved from http://data. worldbank.org/.

Ujianto, Moehaditoyo, Srie Hartutie, dan Amin. 2017. Keuangan Negara dilengkapi Tax Amnesty dan Dilampiri data APBN 20152016. Yogyakarta: Penerbit Indomedia Pustaka.

Untung, Budi. 2011. Hukum Bisnis Pasar Modal. Yogyakarta: Penerbit Andi.

Widoatmodjo, Sawidji. 2009. Pasar Modal Indonesia: Pengantar dan Studi Kasus. Bogor: Ghalia Indonesia.

World Trade Organization. 2015. TBT Information Management System, 2015, Switzerland. http://tbtims.wto.org/web/pages/ search/notification/BasicSearch.aspx (accessed Jan-Aug 2015). 